\title{
Roman og historie
}

\section{Mellem historie og form}

»Romanen overgår alle andre genrer i papirforbrug, " skrev Jean Paul i sin Vorschule der $\ddot{A}$ sthetik, ${ }^{1}$ og det 18. århundredes romaner, både brevromanerne og de pikareske romaner, bredte sig da også ud over siderne, så både forfatter og læser måtte slække på formkravene - eller udvikle nye formkrav så der kunne komme lidt styr på denne opkomling blandt de litterære genrer. Som »novel« eller »novela« var romanen beregnet på at bogføre alle historiske nybrud, og det skabte et særligt intrikat forhold mellem form og historie.

Op gennem det 19. århundrede udviklede forfatterne en form, hvor den løse, episodiske fremstilling afløstes af en strammere fremstilling karakteriseret ved kunstgreb som den alvidende fortæller, den episke præteritum, karakterernes dannelse mv. Med disse midler lykkedes det at udforme en roman, som danner en totalitet, selv om forløbet er rettet mod en åben fremtid. De skilte fortællesituationen fra det fortalte og frigjorde hermed et fortælleperspektiv, hvor de kunne bevæge sig helt tæt på romanens personer og samtidig suverænt overskue spillet mellem disse.

Fortælleren ordnede sit stof, og hans alvidenhed gjorde læseren sikker. Som Georg Lukács anfører i artiklen »Fortælle eller beskrive« kunne læseren derfor føle sig »hjemme i digtningens verden. «"Samme Lukács havde tidligere i sin Romanens teori skrevet, at denne fortrolige, bestjernede verden var gået tabt, og at romanforfatteren og romanens "problematiske helt" led under "transcendental hjemløshed."Hvis det 19. århundredes forfattere kunne skabe fiktioner, der lovede forsoning mellem jeg og omverden, så var der netop tale om fiktioner, og det, der skete i det 20. århundrede, var at disse tryghedsskabende fiktioner ikke længere fungerede. „Fremmedgørelsen«, hvad enten denne nu anskues sociologisk eller psykologisk, blev det store tema i det, som Nathalie Sarraute har kaldt »l'ère du soupçon«: denne "mistænksomhedens tidsalder«, hvor hverken forfattere eller læsere længere fæster lid til, at romanens karakterer er, hvad de giver sig ud for.

1. Jean Paul: Sämtliche Werke, Bd. V, Darmstadt 2000, p. 249.

2. Georg Lukács: Essays om realisme I, København 1977, p. 198. 
At fremmedgørelsen sætter ind, er ensbetydende med, at formerne sætter ud. Der var tale om et epokalt skifte. Hvor historien tidligere havde været kendetegnet ved en kamp mellem gamle udlevede former og nye, levende former, var der nu tale om en kamp mod form som sådan, livets kamp mod formen. Virginia Woolf er nok den, som har givet den mest tilspidsede formulering af dette tidehverv: I essayet »Mr. Bennett and Mrs. Brown« (1924) skriver hun, at romanforfatterne måtte opgive de traditionelle former, for »i eller omkring december 1910 forandredes den menneskelige karakter«, og denne forandring, som omfattede alle sociale relationer, mellem herre og tjener, mand og kvinde, forældre og børn, manifesterede sig mærkbart som »yden af ting der gik i stykker og faldt ned, ting der blev knust og ødelagt. $\ll^{3}$

Woolf sammenligner kritisk James Joyce med en rudeknusende desperado, men hyldede i øvrigt det stimulerende og livsbekræftende i nybruddet. Formløshed kunne således positivt anskues som et overskud af »liv« eller $» k r a f t »$, der transcenderede al »form«. Denne livsfilosofiske løsning understregede imidlertid kun, at der blev sat lighedstegn mellem form og udlevet form, og den genkommende diskussion om romanens død i det 20. århundrede kan lyde som en variant af diskussionen om formens død.

1. verdenskrig blev et omdrejningspunkt for alle disse diskussioner om karakteren, romanen og formen. Lige på tærsklen til 2. verdenskrig trak Sartre disse diskussioner op eller ned i sit signalement af eksistensens kvalme. Og efter 2. verdenskrig stilles spørgsmålet, hvorvidt romanen længere kan levere gyldige udtryk for moderne erfaring.

\section{Romanens nultime}

"Lige efter 45 blev det så utrolig svært bare at skrive en halv sides prosa," bemærkede Heinrich Böll engang. Men markerer '1945' et regulært litteraturhistorisk skel? Noget kunne tyde på det. Man kan f.eks. jævnføre Bölls udtalelse med Theodor W. Adornos berømte dictum om det umulige $\mathrm{i}$ at skrive munter kunst efter Auschwitz. Samme Adorno skrev også i sit essay om fortællerens placering i den moderne roman, at efter 1945 udviklede historien sig til en "permanent katastrofe«, hvor det ville være en »blodig hån« at videreføre den traditionelle realistisk-naturalistiske romanform, fordi den placerede læseren på tryg, uengageret, æstetisk afstand af fortællingens »kukkasse«, der samtidig postulerede at give et objektivt spejlbillede af virkeligheden. ${ }^{4}$ Ganske vist havde allerede Marcel Proust, Franz Kafka og

3. Andrew McNeillie: The Essays of Virginia Woolf, III, London 1988, pp. 421, 434.

4. Th.W. Adorno: Noten zur Literatur, Schriften II, Frankfurt a.M. 1974, p. 46. 
James Joyce skabt et grundlag for en »tidssvarende« roman, der ikke gemte sig i et lukket æstetisk univers, men heller ikke fortabte sig naivt i en episk gengivelse af verdens brogede mangfoldighed. Verdenskrigen og den moderne teknologis nivellering af al erfaring gjorde imidlertid ifølge Adorno negationen til det eneste gyldige udgangspunkt for den moderne romanforfatter - som han så inkarneret i Samuel Beckett.

Et hurtigt, introducerende vue kan antyde, hvordan romanforfatterne i Tyskland, Frankrig, England og USA på forskellig vis skrev sig op fra dette nulpunkt.

De tyske forfattere talte om »Stunde Null« umiddelbart efter krigen, og det er påfaldende, at tre af bidragyderne til denne antologi uafhængigt af hinanden har valgt tysksprogede romaner som alle handler om den nazistiske magtovertagelse: Günter Grass' Bliktrommen (1959) Thomas Bernhards Udslettelse (1986) og Marcel Beyers Flyvende hunde (1995). Günter Grass muntrer sig i optakten til sin fabulerende groteske med en ironisk bemærkning om de moderne teorier om, "at det nu til dags er umuligt at skrive en roman«, og "at der ikke længere findes romanhelte, fordi der ikke længere findes individualister ${ }^{5}{ }^{5}$ men den, som udtaler disse ord, er, som han selv indrømmer det i allerførste sætning, patient på en anstalt for sindslidende. Endnu hos Thomas Bernhard øver nullet en uimodståelig tiltrækning: Romanens titel anslår udtrykkeligt temaet om fuldstændig udslettelse af alle bånd til fortiden, af hele kulturarven.

Også i Frankrig var der nedtælling for romangenren. Den såkaldte »nyroman - »le nouveau roman« - her repræsenteret ved Michel Butor - var en "nul-roman, " som negerede alle overleverede forestillinger om plot, person og point of view. Om "personromanen« skrev Alain Robbe-Grillet således i Pour un nouveau roman (1963), at verdens skæbne ikke længere kan identificeres med nogle enkeltmenneskers opstigning og fald; at verden ikke længere er et stykke privatejendom, man kan erobre; og at »den nuværende tidsalder snarere står i indregistreringsnummerets tegn«. ${ }^{6}$ I forordet til en af de første "ny romaner«, Nathalie Sarrautes Portrait d'un inconnu (Portrcet af en ukendt) (1948), skrev Jean Paul Sartre udtrykkeligt, at den nye roman måtte blive en antiroman. ${ }^{7} \mathrm{Og}$ få år senere, i 1953, erklærede Roland Barthes i Litteraturens nulpunkt, at viserne pegede mod et »romanens nulpunkt.»

I England indledte Iris Murdoch i 1961 i essayet »Against Dryness» en polemik mod den moderne romans opgivelse af den traditionelle romans dynamiske sammenfletning af individ og klassebaggrund. Hun mente, at

5. Günter Grass: Bliktrommen, Kbh. 1985, p. 13.

6. Alain Robbe-Grillet: På vej mod en ny roman, Fredensborg 1965, p. 28

7. Nathalie Sarraute: Portrait d'un inconnu, Paris 1956, p. 7. 
romanen op gennem det tyvende århundrede havde spaltet sig ud i en formløs, journalistisk retning, hvor forfatteren fortaber sig i facts, og en formstreng, krystallinsk retning domineret af små, stramme, quasi-allegoriske beretninger om »menneskets lod.« Den sidstnævnte, »tørre« retning danner med sin selvtilstrækkelighed en analogi til det ensomme, selvtilstrækkelige individ, og konfronteret med dette næsten-nulpunkt efterlyste Murdoch en roman med karakterer, der udfolder sig i en historisk og social ramme. ${ }^{8}$ A propos 1945 skal det tilføjes, at Murdoch umiddelbart efter 2. verdenskrig som officer deltog i den internationale indsats for flygtningehjælp, og at hendes egne romaner er tæt befolket med skæbner, hun mødte under dette arbejde.

I USA inspirerede krigen også til en nulpunktslitteratur - som allerede titlen afslører på Norman Mailers The Naked and the Dead (De nøgne og de døde) (1948). Myte og modernisme gled i baggrunden, og en forfatter som Mary McCarthy argumenterede både gennem sine romaner og sine essays for en ny, skeptisk realisme. Men mange fandt det vanskeligt at etablere en forbindelse mellem realismen og den menneskelige skala, som jo er kernen i al humanisme. I 1963 skrev en af efterkrigstidens mange store jødisk-amerikanske forfattere, Saul Bellow, essayet "Some Notes on Recent American Fiction«, hvor han konstaterede, at individet i denne nyeste amerikanske prosa var presset af et enormt offentligt liv, der reducerede ham til dværgestørrelse som individ, samtidig med at det lod ham blive en kæmpe i sit had og i sin fantasi. " Sort humor - eller ironisk nihilisme - lever imidlertid af skalabrud, og Joseph Heller satte med titlen på sin antikrigsroman Catch 22 (1961) navn på den perverse logik, som siger: At den som vil undgå krigstjeneste må erklæres sindssyg, men at dette imidlertid ikke kan lade sig gøre, da den som vil undgå krigstjeneste jo må være rask i hovedet. Efter »Catch22 «logikken skabte en stribe amerikanske forfattere - Kurt Vonnegut, Ken Kesey, Thomas Pynchon m.fl. - en romanform, hvor nulpunktet blev trukket op med stadig længere og stadig mere slyngede linjer gennem den moderne verden.

\section{Romanens midnatstime}

Mens nultimen slog i Europa, slog midnatstimen uden for Europa - som skildret af Salman Rushdie i Midnatsbørn. Ganske vist rummede slagene mange ekkoer fra den vestlige litteratur. Rushdie selv sender tydelige

8. Iris Murdoch: »Against Dryness«, in Encounter, January 1961, pp.16-20.

9. Saul Bellow: »Some Notes on Recent American Fiction«, in Encounter, Nov.1961, pp.22-29. 
hilsener til bl.a. Günter Grass, og lader sin fortæller i Midnatsbørn erklære den indiske litteratur "a grotesque mimicry of European literature.« Men nu er Rushdie selv blevet et forbillede for mange europæiske forfattere.

Den litterære afkolonialisering tog sin begyndelse efter 1945. I sin indledning til Frantz Fanons Fordømte her på jorden (1961) skriver Jean Paul Sartre, at europæerne er »færdige«, at Europa "springer læk overalt», og at europæerne »blodigt« må udrydde europæeren i sig selv, hvis de vil overleve i en ny verden uden kolonier. ${ }^{10}$ Man kan måske tolke Bruce Chatwins mønsterdannende rejseromaner fra Australien og Patagonien som eksempler på en sådan selvforvandlende afkolonialisering. Under alle omstændigheder er det et slående træk ved litteraturhistorien siden 1945, at forfattere fra de tidligere kolonier har tilført romangenren nyt stof, ny kraft. Som cubaneren Alejo Carpentier formulerede det:

»Når man betragter den moderne europæiske roman (o. 1975), er det evident, at den er i krise, ikke m.h.t. kvalitet, men m.h.t. tematik. Hundredvis af romanforfattere fra det gamle kontinent skriver psykologiske romaner, der er døde fra fødslen, fordi de smadres af epos'et, den moderne histories epopé [...] Lad os vende blikket mod vort Amerika. Her er det episke, både det frygtelige og det smukke i det episke en hverdagserfaring. [...] Den latinamerikanske roman stræber henimod det episke. $\ll^{11}$

Siden Carpentier signerede denne dødsdom over den moderne europæiske roman, har denne inspireret af latinamerikanske forfattere som Carpentier selv, Miguel Angel Asturias, Gabriel García Márquez, indiske forfattere som Salman Rushdie, Vikram Seth, Anita Desai, Amitav Ghosh, afrikanske forfattere som Nadine Gordimer, J.M. Coetzee, Tahar Ben Jelloun og Ben Okri genoptaget den store episke tradition.

Allerede i 1827 udmøntede Goethe begrebet verdenslitteratur, men det er først efter 1945, at hele verden med Erich Auerbachs ord er blevet »vort filologiske hjem «. ${ }^{12}$ Selv om Frantz Fanon efterlyste en »national kultur«, og selv om antiimperialistiske forfattere som Miguel Angel Asturias har udfoldet sig i en opdateret nationalromantik, er nationen ikke længere det filologiske hjem. Hvis man blot tager Danmark som eksempel, er det slående, i hvor høj grad den store latinamerikanske roman har inspireret forfattere som Henrik Stangerup, Ib Michael, Jens Smærup Sørensen, Peter Høeg, og

10. Frantz Fanon: Fordømte her på jorden, Kbh. 1968, pp. 9-23.

11. Alejo Carpentier: „Problematica del tiempo y el idioma en la moderna novela latinoamericana", in Ensayos, Ciudad de la Habana 1984, pp.138, 140.

12. Erich Auerbach: Philologie der Weltliteratur, Frankfurt a.M. 1992 
man kan citere Hans-Jørgen Nielsen, der i 1981 i essayet »Episk, mytisk» trækker en direkte linie fra sin læsning af Gabriel García Márquez og Manuel Scorza til opdagelsen af det fabulerende fortælletalent hos sin »episke mor. ${ }^{13}$

\section{Romanen som skalamodel}

José Ortega y Gasset sammenligner i Ideas sobre la novela (1925) romanlæseren med en skibbruden, der omgivet af roman til alle sider først ved slutningen - med opspilede øjne - redder sig i land. ${ }^{14}$ Romanforskeren, der søger at kortlægge linjer i romanens historie, her romanens historie siden 1945, er i endnu højere grad ude på dybt vand. Men belært af romanforfatteren kan romanforskeren betjene sig af det greb, som ifølge Claude Lévi-Strauss er selve kernen i al æstetisk indstilling: Skalareduktion. Det, som undslipper sansernes umiddelbare kapacitet, må reduceres til et format, hvor det bliver muligt at fange det i ét blik, i ét greb. Det uoverkommelige må gøres overkommeligt. Herunder de seks millioner otte hundrede ti tusind liter vand i sekundet, som Michel Butor sætter sig for at repræsentere i sin roman af samme navn.

Inden for romankunsten kan skalareduktionen manifestere sig negativt, som i de tilfælde, hvor det Milan Kundera i Romankunsten kalder »reduktionstermitterne« nedbryder al form og al struktur:

»Den globale histories enhed, denne humanistiske drøm, som Gud ondskabsfuldt har ladet gå i opfyldelse, ledsages af en svimlende reduktionsproces. Reduktionstermitterne har ganske vist altid gnavet i menneskenes liv (...) Men det moderne samfunds karakter forstærker i uhyrlig grad denne forbandelse. ${ }^{15}$

I følge Kundera henter romanen sin eksistensberettigelse i sine bestræbelser på at "holde "livets verden« under stadig belysning« og derved modvirke reduktionismen, "men ak, også romanen bearbejdes af reduktionstermitterne.... $\|^{16}$

Når det lykkes romanen at kaste nyt lys over det moderne samfund, kan den betjene sig af en anden, positivt anskuet skalareduktion, hvor den fremdrager væsentlige sammenhænge. Italo Calvino påpeger således i essaysam-

13. Hans-Jørgen Nielsen: »Episk, mytisk. Min episke mor«, in Kritik 60 (1982), p. 119.

14. José Ortega y Gasset: »Ideas sobre la novela«, in Obras Completas, III, Madrid 1957, p. 410.

15. Kundera, Milan: Romankunsten:essat, København 1987, p. 24.

16. Op.cit., p. 25. 
lingen Til det noeste årtusind, at det karakteristiske for "vor tids roman« er, at vi forefinder den "som encyklopædi, som erkendelsesform, og især som sammenbindende net mellem hændelser, personer, tildragelser i verden. ${ }^{17} \mathrm{I}$ mellemkrigstiden manifesterede denne encyklopædiske ambition sig i gigantiske værker som Mikhail Sholokovs Stille flyder Don (1928-40), Jules Romains' De gode viljer (1932-46) og Roger Martin Du Gards Familien Thibault (1922-39), men efter 1945 er tiden ikke til sådanne lange romaner, i hvert fald ikke hvis man skal tro Calvino selv, der i Hvis en vinternat en rejsende (1979) lader fortælleren udtale, at »lange romaner er noget af en selvmodsigelse i dag; tidens dimension er sprængt i stumper og stykker... ${ }^{18}$

Den moderne roman har i stigende grad udskiftet tidens dimension med rummets dimension, og den encyklopædiske dimension manifesterer sig som en spatial kortlægning. Doris Lessing indledte i 1979 under genrebetegnelsen »space fiction« en udgivelse af romanserien Canopus in Argos, hvor den bærende ide er, at planeten Canopus besidder et arkiv med viden og fortællinger om næsten alt i universet. Et storstilet eksempel på en encyklopædi, der dog holder sig til jorden, er George Perecs Livet. En brugsanvisning (1999). Men også close ups på helt snævre verdener kan afdække nye facetter af »livets verden, «jfr. f.eks. Jean Philippe Toussaints Badevorelset og Nicholson Bakers Rulletrappen. Mellem disse to yderpunkter finder man et ikke ringe antal eksempler på nyere romaner, der tager realeksisterende skalamodeller af verden som udgangspunkt for en litterær skalareduktion. Verdensudstillingen er kroneksemplet på en sådan skalamodel, og her kan fra den nyere romanlitteratur nævnes eksempler som E.L. Doctorows Verdensudstillingen (1985), Eduardo Mendozas Miraklernes by (1988) og Erik Orsennas L'Exposition coloniale (1988).

Som et sidste eksempel på skalareduktion i den moderne litteratur kan nævnes de humoristiske kortslutninger mellem verdenshistorie og personalhistorie. I Salman Rushdie's Midnatsbørn fødes hovedpersonen i den time, hvor Indien opnår uafhængighed, og han er, som han selv udtrykker det, gennem hele sit liv »lænket med håndjern til Historien«. ${ }^{19}$ I Einar Már Gudmundssons Universets engle (1993) præsenterer fortælleren sig som en rygende viking fra Reykjavik, "født på Rigshospitalets fødeafdeling d. 30. marts 1949, samme dag som Island trådte ind i NATO. ${ }^{20} \mathrm{Og}$ i Carlos Fuentes' Kristoffer Ufødt (1987) undfanges fortælleren på en strand ved Acapulco præcis 9 måneder før 500-års jubilæet for Columbus’ opdagelse af Amerika, og sejlende omkring i fostervandet rapporterer han over 500 sider

17. Italo Calvino: Til det næste årtusind. Amerikanske forelæsninger, Kbh. 1995, p. 109.

18. Italo Calvino: Hvis en vinternat en rejsende, Kbh. 1997, p. 9 f.

19. Salman Rushdie: Midnatsbørn, Kbh. 1996, p. 9

20. Einar Már Guðmundsson: Universets engle, Kbh. 2001, p. 14. 
om den gradvise opdagelse af det moderne Mexico, han står i begreb med at skulle erobre. Humor skærer tingene ned, så man kan håndtere dem, og denne humoristiske kortslutning mellem verdenshistorie og personhistorie gør det muligt at føje et globalt perspektiv ind i en genre, som har (haft) sin force i fremstillingen af enkeltskæbner.

\section{To linjer i romanens historie}

Ligesom romanforfatteren må romanforskeren stræbe efter at fange de store linjer i udviklingen uden at arbejde med så stormaskede kategorier, at alt det interessante falder lige igennem og ender som flade og ligegyldige iagttagelser. Værdien af de litteraturhistoriske skalamodeller må vise sig ved sammenholdning med analysen af konkrete enkeltværker. Her kan den store linjeføring imidlertid støtte sig til et udsagn af en forfatter, Jan Kjærstad, der i essaysamlingen Menneskets felt (1999) foreslår en tvedeling af romanfeltet, idet han bl.a. henviser til nogle af de forfattere, som behandles i denne bog:

"Lidt firkantet kan man sige, at der eksisterer to store romantraditioner i vores århundrede. Den ene lægger vægt på skriftstemmen, på det rene og poetiske (Woolf, Beckett, Handke, Bernhard). Den anden tradition - den fabulerende roman - lægger vægt på det episke, den gode historie (Grass, Calvino, Tournier, García Márquez, Angela Carter, Peter Carey). $\|^{21}$

Hvor Iris Murdoch kritiserede polariseringen mellem en krystallinsk og en journalistisk linje i romanhistorien, skelner Kjærstad positivt mellem to hver for sig værdifulde linjer: »den rene stemmes« romaner og »de fabulerende, episke«. Denne opdeling minder igen om Salman Rushdies distinktion mellem den eksklusive og den inklusive roman. Under henvisning til sin egen Midnatsbørn - hvis 30 kapitler i øvrigt er konciperet som 30 revnende fulde chutney-beholdere - bemærker han i et interview:

„En af grundene til, at romanen er så lang, skyldes ideen om, at en roman skal inkludere så meget som muligt. Det forekommer mig, at der kun findes to slags romaner. Der er de romaner, der som udgangspunkt udelukker det mest af verden ved at uddrage den ene tråd i hele universet, som de så skriver om. $\mathrm{Og}$ så er der de romaner, som man forsøger at få til

21. Jan Kjærstad: Mennekets felt. Essays om litteratur, Kbh. 1999, p. 19 f. 
at rumme alt, dens slags som Henry James kaldte fiktionens »løse, posede monstre. $\|^{22}$

Kjærstad, Rushdie og Grass har alle plejet mest omgang med disse monstre, men det er ikke ensbetydende med, at der ikke kan finde en frugtbar udveksling sted mellem de eksklusive og de inklusive forfattere. Günter Grass fortæller, at han under udarbejdelsen af Bliktrommen blev hjulpet af samtaler med digteren Paul Celan, og han føjer til, at han ikke kan forklare det paradoks, at Paul Celan med dennes »indsnævring« af litteraturen således kunne stå fadder til en af århundredets mest fabulerende romaner.

De to romantraditioner udelukker ikke nødvendigvis hinanden. Og der gives eksempler på, at en og samme forfatter kan skrive inden for begge traditioner. I denne samling af analyser behandles to romaner af Don DeLillo. Den ene, Underverden, er maximalistisk, vildt ambitiøs, encyklopædisk i sit sigte og lige så "uren« fabulerende i sin form, som det affald, romanens hovedperson lever af at analysere. Den anden, derimod, Kropskunstneren, er minimalistisk, næsten skrabet i sin bestræbelse på at uddestillere poesi af hverdagens prosa. Men også den monstrøse Underverden betjener sig af skalareduktion: Hele dens univers findes fortættet i den baseball, som Bobby Thomson slog, da han lavede et home run under den berømte kamp mellem Dodgers og New York Giants den 3. oktober 1951.

De to romantraditioner kan også samles i én, ganske vist meget speciel romanform, som man ser det i østrigeren Thomas Bernhards Udslettelse, der bærer den meget rammende undertitel: Ein Zerfall, på dansk oversat til En nedbrydningshistorie. Romanen er omfangsrig og vildt associerende som de »inklusive«, fabulerende romaner, men alle associationer er lagt i munden på én gennemgående fortællerstemme, hvis udsigelse består i én lang undsigelse af verden i almindelighed og Østrig i særdeleshed. Den monomane, paranoide, men på sin egen måde også poetiske stemme tilhører den 46-årige Franz-Josef Murau, som i sit sidste leveår forfatter nogle optegnelser - romanen! - der med sprogets værste gloser udsletter og "udslukker« alt det, som fortælleren kommer fra: Familien, landsbyen Wolfsegg, Østrig, hele den ulidelige alliance mellem katolicisme, nationalsocialisme og småborgerlighed. Som fortælleren selv anfører, får optegnelserne titlen Auslöschung eller Udslettelse, fordi "min beretning har kun et mål og det er at udslette det, der berettes om, udslette alt det, jeg forbinder med Wolfsegg, og alt det, som Wolfsegg er. $\ll^{23}$

22. Salman Rushdie: »Midnight's Children and Shame», in: Kunapipi 8, nr. 1 (1986), p. 10.

23. Thomas Bernhard: Udslettelse. En nedbrydningshistorie, Århus 1998, p. 123. 


\section{Panorama og andre kunstgreb}

Også i det 19. århundredes roman finder man apokalyptiske fantasier om al tings udslettelse, men langt det dominerende perspektiv er dog den fiktive rekonstruktion af en verden, som under den voldsomme modernisering let kunne ligne en verden, hvor alt var i opløsning: "All that is solid melts into air», som Marx og Engels skrev i Det kommunistiske manifest(1848). Rekonstruktionen krævede kunstgreb, og i det 19. århundredes roman blev det panoramiske blik udviklet som det vigtigste greb til reduktion af en verden kendetegnet ved hastigt ekspanderende storbyer, stadig videre horisonter. Honoré de Balzac placerede gerne sine personer på Pére Lachaise-kirkegård eller på andre højtliggende steder, hvor de havde fuldt overblik over Paris; Victor Hugo placerede i Notre Dame sin fortæller så højt, at han fra sit fugleperspektiv kunne overskue Paris hele kompasset rundt, og Charles Dickens, som fantaserede om et kilometerlangt "moving panorama " af London, krydsede igen og igen det labyrintiske fodgængerperspektiv med fugleperspektivet fra spir og tårne.

Drømmen om, at den enkelte som en eksistentiel feltherre kan kaste sit altbeherskende blik 360 grader ud over verden, er ikke helt gået i stykker for det 20. århundredes forfattere. Milan Kundera benytter sig af dette greb, når han i Udødeligheden placerer sin fortæller i et motionsrum højt hævet over byens tage, "hvorfra man gennem store vinduer har udsigt over hele Paris. $\|^{24}$ Men hvor drømmen lever, er bevidstheden om at det er en drøm større - hvis da ikke drømmen bliver et mareridt. I Den sorte bog sender Orhan Pamuk sin helt, advokaten Galip, ud på en labyrintisk færd gennem Istanbul, og undervejs skaber han en fiktion om "Øjet« eller »Ham«, som dels er den person, han selv ønsker at blive, dels »en monstrøs skabning skabt af den vrimmel jeg havde set defilere forbi mig «. ${ }^{25}$ "Øjet« er kendetegnet ved et "altskuende og altdømmende« blik, der hænger over hans hoved som en evig sol, og der er tydeligvis ikke langt fra det panoramiske til det paranoide. Fortælleren erklærer sig ganske vist »særdeles tilfreds med det strålende lyspanorama, som »øjet« gav mig«, men kapitlet om øjet slutter »i et ufatteligt mørke ${ }^{26}{ }^{26}$ Det altskuende blik er en uholdbar illusion.

Hvor det 19. århundredes romaner - groft sagt - stræbte efter at indfange én realitet og én historie i deres litterære panoramaer, arbejder det 20.

24. Milan Kundera: Udødeligheden, Kbh. 1996, p. 9.

25. Orhan Pamuk: Den sorte bog, Kbh. 1996, p. 125.

26. Op.cit., p. 128. 
århundredes romaner med flere lag og andre kunstgreb. Georges Perec kalder vittigt og rammende sin Livet - en brugsanvisning for "romaner" sætter altså genren i flertal - og rammen om disse »romaner« er en fleretages pariser-ejendom. Den moderne roman kan imidlertid både vælge den vertikale model med lag på lag og den horisontale model med lag ved lag - eller simpelthen foretage uberegnelige brud med begge disse modeller. I det første tilfælde har man enten den mytiske roman, hvor moderne skikkelser og tilskikkelser følger arketypiske forbilleder, eller den metafiktive roman, hvor teksten træder i rapport til andre, mere eller mindre forbilledlige tekster. I det andet tilfælde har man listen som fremstillingsprincip. Og i det tredje tilfælde finder man groteskens dyrkelse af undtagelsestilfældet.

I den klassiske roman, som den blev udviklet i det 19. århundrede, kombineredes gennem det panoramiske perspektiv mening, plot, erfaring og realisme. I det 20. århundredes romaner betegner de nævnte fire kunstgreb en ironisk markering i forhold til den klassiske roman. Meningen er blevet "afløst« af myten; plottet på én gang realiseres og derealiseres gennem det metafiktive perspektiv; erfaringen har måttet vige for mer eller mindre ambitiøse lister; og realismen har antaget en grotesk drejning. De følgende fire afsnit vil skitsere, hvordan disse fire kunstgreb praktiseres.

\section{Myten}

I de første årtier af det 20. århundrede udviklede forfattere som Marcel Proust, Franz Kafka, Thomas Mann og James Joyce kunstgreb, der etablerede en ny balance mellem det historiske stof og romanens form. Der var ikke længere psykologisk eller politisk dækning for den symbolske form, der blev udviklet i det 19. århundrede, kendetegnet ved den alvidende fortæller, den store handling, den sammenhængende tid og den gennemgående karakter. Dannelsesromanen og den historiske roman blev afløst af former, der satte spørgsmålstegn ved disse kunstgreb. Det vigtigste (og vanskeligste) af disse er her myten.

„Oprindelig« er mytens kodeord, og oprindelig var myten opfattet som en sand fortælling om, hvordan verden eller en del af verden er blevet til. Den var en sand fortælling om, hvordan »det hellige« griber skabende eller ordnende ind i verden. Myten tilbyder således forklaringer, hvordan noget er blevet til, i modsætning til historien, der opsøger årsagssammenhænge. Man kan sige, at den i sit anlæg forudsætter tro, hvor historien og herunder også historien i romanform har sit udgangspunkt i tvivl og skepsis. I myten hviler alt på en gentagelse af den oprindelige, skabende handling, mens historiens element er forandringen. I myten er det først gentagelsen, som giver et 
fænomen virkelighed, og myten kan derfor betragtes som et forsøg på at undslippe historien.

I (det uoversatte) forord til Riget af denne verden, som er et pionerværk inden for den såkaldte magiske realisme, skriver Alejo Carpentier, at »det mirakuløse« begynder dér, hvor der pludselig sker en illuminering af virkeligheden, og han tilføjer, at denne åbenbaring»forudsætter en tro«. ${ }^{27}$ Men lige præcis spørgsmålet om »tro« er det, der gør det vanskeligt at tolke mytens funktion i den moderne roman. Udviklingen af den magiske realisme hos Alejo Carpentier selv, Miguel Angel Asturias, Juan Rulfo og Gabriel García Márquez afslører de problemer og paradokser, den moderne forfatter må forholde sig til, når han vil slå bro over magi og realisme, myte og historie, occidental identitet og primitive kulturers alteritet.

Hovedskikkelsen i mytiseringen af den moderne roman er James Joyce, men myten i Ulysses (1922) tolkes som regel mere som udtryk for en metode end som udtryk for en tro. $\mathrm{Og}$ når spørgsmålet om tro dukker op, besvares det som regel med en henvisning til den ironiske og kritiske dimension i Joyces mytiske kobling mellem det gamle Grækenland og Irland anno 1904. Men mytens anti-historiske funktion blev understreget af T.S. Eliot, der skrev, at den "mytiske metode« gjorde den moderne, formløses og fragmenterede verden tilgængelig for litterær behandling.

Peer Hultberg siger i et interview om »romanens rum«, at Joyce reducerer myten til en måde at holde tingene sammen på, og tilføjer, at efter han opfattelse er myten ikke kun et spørgsmål om struktur, men også om kultur: „vi lever til en vis grad mytisk«, "vi lever mytologiske liv«. ${ }^{28}$ Myten bliver det sted, hvor man midt under historien med dens forandringer kan falde ind i en gentagen sammenhæng og »komme til at leve«. Her er myten en løsning på fremmedgørelsens problem: Vi ved det måske ikke, men bagom ryggen på os anviser myten os plads i kendte mønstre.

I den moderne roman mødes myten snart med patos, snart med ironi, og snart kan individuelle, snart overindividuelle konjunkturer forklare de skiftende holdninger til myten. Ernst Cassirer har i The Myth of the State (1946) med nazismen som eksempel argumenteret for, at sammenbrud i den sociale orden kan føre til desperat genoptagelse af primitive tankeformer midt i den moderne verden, og det, som nazifilosoffen Arthur Rosenberg kaldte Mythos des zwanzigsten Jahrhunderts, betød en voldsom kompromittering af myten.

27. Alejo Carpentier op.cit., p. 77.

28. Erik Granly Jensen: »I romanens rum, Interview med Peer Hulterg«, in Standart, 10. årgang, nr. 1 (1996). 
I 1945 skrev den Joyce-inspirerede Hermann Broch imidlertid et essay om digtningens mytiske arv, hvor han anførte, at det 20. århundredes erfaringer med global grusomhed havde fremkaldt apokalyptiske følelser, men havde samtidig beredt vejen for mytens genfødsel. Romanen skulle ikke kun underholde og belære, men artikulere almene og tidløse værdier. I et efterfølgende essay fra 1947 om mythos og aldersstil tilføjede han, at Hitlers "nye mythos« kun var en pseudo-myte, fordi den fornægtede eller forbød »de menneskelige problemer", som netop er den sande mytes anliggende. Med romanen om Vergils død (1945) satte han i denne "sande mytes" ånd tingene på spidsen gennem sin skildring af dødsøjeblikkets intense udveksling mellem alt og intet, mellem politisk fællesskab og privat erfaring. Og spørgsmålet er, som det fremgår af de efterfølgende analyser, taget op igen af Maurice Blanchot og Milan Kundera, som begge har hentet varig inspiration i Brochs forfatterskab - her Blanchot i $A$ l'instant de ma mort og Kundera i Udødeligheden.

\section{Metafiktion}

Myten og det man kunne kalde den intertekstuelle metafiktion minder om hinanden. I begge tilfælde har den nærværende tekst et fraværende forbillede, som bestemmer dens form og figurer. Men hvor myten i sit væsen kræver tilslutning og tro og derfor trækker på forbilledet som en arketype, står metafiktionen i et mere ironisk forhold til sit forbillede - og forbilledet er netop andre fiktioner, ikke andre myter.

"Nultimen« efter 1945 betød, at der blev sat spørgsmålstegn ved alle forbilleder, både mytiske og fiktive forbilleder, og man kunne let få det indtryk, at romanens virkelige fjender var plot, karakter og miljø, og i efteråret 1966, modtog John Fowles den inspiration, som han tre år senere udmøntede i romanen Den franske løjtnants kvinde, hvor han systematisk fordobler han plot, karakter og miljø i en guvernanteroman, som de kendes fra det 19. århundrede, og en selvreflekteret roman med moderne figurer og konflikter. I romanens trettende kapitel giver fortælleren følgende svar på spørgsmålet om, hvem løjtnantens kvinde er:

"Jeg ved det ikke. Den historie jeg fortæller er ren fantasi. De personer jeg skaber har aldrig eksisteret uden for min hjerne. Hvis jeg indtil dette punkt har foregivet at kende mine personers sjæle og inderste tanker, er det, fordi jeg skriver i (ligesom jeg har antaget noget af ordforrådet og "stemmen" af) en konvention, der var alment anerkendt på den tid min historie foregår i: nemlig at romanforfatteren kommer lige efter Gud. 
Han ved måske ikke alt, men han prøver dog at lade, som han gør. Men jeg lever i Alain Robbe-Grillets og Roland Barthes' tidsalder: hvis det her er en roman, kan det ikke være nogen roman i den moderne betydning af ordet. $\ll^{29}$

»Dette er ikke roman i den moderne betydning af ordet», siger fortælleren, men henvisningen til Robbe-Grillet og Barthes viser, at metafiktionens kontrastering af 1860erne og 1960erne kan være lige så kritisk over for traditionelle forestillinger om handling og karakter som den mere radikalt eksperimenterende roman. I essayet "Against Dryness« bemærker Iris Murdoch, at "virkelige mennesker er ødelæggende for myten «, ${ }^{30}$ men Fowles opnår med sit dobbeltgreb både at skabe sådanne "virkelige mennesker« og at skabe en moderne bevidsthed om, at denne virkelighed bygger på konventioner.

Den metafiktive form kan tjene forskellige formål, og man kan ikke uden videre finde en fælles fortolkningsnøgle til f.eks. Fowles' Den franske løjtnants kvinde, Milan Kunderas Udødeligheden, J.M. Coetzees Foe. Når det gælder Fowles og Kundera, fungerer metafiktionen som intern mytekritik, jfr. Kundera der spejler sin moderne historie i historien om den bande blege romantikere, som omkring år 1800 »havde bemægtiget sig Tyskland. $\|^{31}$ Coetzee, derimod, foretager en ekstern mytekritik ved at vende Daniel Defoe's forsvar for kolonialismen på hovedet. Man kan også med de traditionelle begreber for dobbeltkodede fortællinger sige, at den vesteuropæiske metafiktion domineres af pastichen, der kombinerer nostalgi med ironi, mens metafiktion fra de forskellige hjørner af den tredje verden domineres af parodien, der kan være nådesløs i sin storm på forbillederne.

Når England synes at have været særlig leveringsdygtig i metafiktion skyldes det formentlig, at det var det engelske imperium, der i det 19. århundrede blev den førende kolonimagt - med støtte fra det 19. århundredes store romanforfattere - hvorfor det 20. århundredes englændere fik særlig vanskeligt ved at opgive den stolte fortid. I 1967 udgav Rubin Rabinovitz således en bog med titlen The Reaction Against Experiment in the English Novel: 1950-1960, og selvom tiåret også bød på eksperimenter i den engelske romanlitteratur, er det påfaldende i hvor høj grad den victorianske tidsalder og dermed den victorianske roman fortsat var en levende udfordring. Iris Murdochs Klokken (1958), John Fowles’ Den franske løjtnants kvinde

29. John Fowles: Den franske løjtnants kvinde, Kbh. 1994, p. 89.

30. Murdoch loc.cit. (se note $\mathrm{xx}$ )

31. Milan Kundera: Udødeligheden, Kbh. 1990, p. 103. 
og A.S.Byatts Bescettelse (1990) er blot nogle få af de mange eksempler på dette.

Michael Cunninghams Timerne - som analyseres nærmere i dette nummer af $K \& K$ - springer i sin dobbeltkodning ud af det victorianske ekkorum, og vælger da som sit metafiktive omdrejningspunkt Virginia Woolf, som er den engelske forfatter, der med det føromtalte essay om »Mr. Bennett og Mrs. Brown« har givet de skarpeste formuleringer af modsætningen mellem victoriansk og moderne romankunst. Cunningham tager Mrs. Dalloway fra 1925 som udgangspunkt for en metafiktion, der kombinerer tre epoker, tre handlinger og tre karakterer.

\section{Listen}

Panoramaet og myten tilbyder hver på sin måde helhedsdannelser, ligesom romanens plot er redskab for en totalisering, der indordner og underordner sig romanens stof. Men siden 1945 har listen, som er båret af et helt andet formprincip, vundet udbredelse inden for romanen. Listen er en helt åben form, der er kendetegnet ved en principielt uendelig række af elementer. Samleren er den figur, som i særlig grad dyrker listen, men samlingen er en helhed, der forudsætter spredning, og enhver afslutning er imod samlingens væsen. Jf. Alejo Carpentier, der selv dyrker listen i sin lærd-surrealistiske prosa, og som i et essay om El amor a la ciudad (=Kærlighed til byen) (1997) skriver:

»Under mine vandringer i Havana, som jeg elsker mere end nogen anden by i verden, har jeg mange gange spurgt mig selv, om dens skæbne ikke har været styret af eventyrligere samlere af huse, avenyer, moler, parker og offentlige bygninger, dvs. mennesker der frygter, at deres lyst skal afslutte med opnåelse af et perfekt værk. $\star^{32}$

Listen har en særligt fremtrædende placering i amerikansk litteraturhistorie. Walt Whitman introducerede listen som poetisk figur i sine katalogdigte, og hans verbale erobring af det nye kontinent inspirerede ikke kun Pablo Nerudas Canto General (1950), men også Jorge Luis Borges' Fiktioner (1944), og nøgleskikkelserne inden for den magiske realisme dyrkede listen som en form, der kunne løse paradokset: at tegne et realistisk spejlbillede af en virkelighed, der trodsede alle kendte forestillinger, jf. García Márquez der i sin

32. Alejo Carpentioer: El amor a la ciudad, Madrid 1997, p. 65. 
takketale for Nobelprisen introducerede begrebet »la realidad desmesurada» - dvs. den umådeholdne virkelighed.

Listen bryder, som Kjærstad har udtrykt det, med stetoskopets poetik, der retter opmærksomheden mod centrum, og introducerer i stedet teleskopets poetik, der opsøger netværk og søger at etablere koordinater i periferien. Borges opfattede (undertiden) sig selv som en eksileret europæer, men priste samtidig sin placering i periferien, fordi den gav ham et samlet og uhildet perspektiv på den europæiske kultur.

Lister og latinamerikansk inspiration finder man også i Bruce Chatwins værk, men her kombineret med hans erfaringer som samler. Inden han blev forfatter, var han ansat ved auktionsfirmaet Sotheby's i London, og connoiseurens fiksering ved enkeltgenstande er videreført i hans litterære værker, fx. I Patagonien som er struktureret som en samling af kuriøse historier fra "verdens ende«. De enkelte historier er trukket ud af en overordnet historisk sammenhæng for i stedet er blive linet op side om side, hvor de tjener som afmærkning af den indsamlende forfatters personlige verdensorden.

I Thomas Pynchons Katalognummer 49 udbydes røber allerede titlen, at auktionen og dermed samlingen er den åbne ramme om romanens univers. Hovedpersonen Oedipa Maas er en sandhedssøgende Ødipus, der vikler sig ind i stadig mere labyrintiske intriger, men hendes efterhånden paranoide jagt på én mening, der kan kaste lys over forviklingerne, kontrasteres med mangfoldigheden i alt det, der ikke er underlagt en mening. Frimærkesamlingen med dens "tusinder af små farvede vinduer til dybe panoramaer i rum og tid« bliver et billede på denne mangfoldighed. Selv individet, som pr. definition er »udeleligt«, inkarnerer mangfoldigheden. Svarende til Whitman, der i Song of My Self skriver »I am large, I contain multitudes«, karakteriseres en af personerne i Katalognummer 49 udbydes som »en omvandrende menneskemængde. $\ll^{33}$

Hvor Pynchon understreger listens åbenhed over for den dæmoniske mening, som lukkes inde i et planetarium eller en kuppel eller en anden »black box«, skildrer Marcel Beyer i Flyvende hunde en dæmonisk bestræbelse på at lukke listen. Hovedpersonen Hermann Karnau er akustiker i Hitlers Tyskland, og han samler lyde for at opnå totalt herredømme over de sjæle, der manifesterer sig i stemmen. Selv kalder han sig en slags »landmåler« af menneskemateriale, og slagmarken bliver et privilegeret indsamlingsfelt for denne landmåler:

33. Thomas Pynchon: Katalognummer 49 udbydes, Kbh. 1968, p. 126. 
»Nu er slagmarken fyldt med såredes råb. Skifter som i barnlig feber bestandig mellem lydindgangene, lægger nye bånd i, sidder og rækker efter materialekufferten. Landkortet over vokalerne. ${ }^{34}$

\section{Grotesken}

Hvis formløsheden har en form, må det være grotesken, og man har en lang litteraturhistorisk tradition for grotesker, men på tærsklen til det 20. århundrede rejser formløshedens problem sig på en ny baggrund og med nye konsekvenser for forfatterne. Grotesken er et symptom på manglende formning af stoffet, og dette symptom har siden Kafka spredt sig med epidemisk hast i moderne litteratur.

Det felt, hvor grotesken i særlig grad fik lov at udfolde sig, var feltet mellem det offentlige og private, som romanen oprindelig - hos det 18 . århundredes forfattere - havde bidraget til at fastlægge. Forholdet mellem de offentligt forpligtende former og den private verden forrykkede sig, og man kan med David Daiches sige, at hvor det 19. århundredes roman var forankret i en verden af offentlige værdier, som deltes af forfatter og læser, introducerede Joseph Conrad på tærsklen til det 20. århundrede som den første engelsksprogede forfatter romaner med situationer, hvor »alle offentlige formuleringer af menneskelige standarder og menneskelige motiver var inadækvate. ${ }^{35}$

I denne samling af analyser kan der trækkes en lige linje fra Günter Grass' Bliktrommen til Salman Rushdies Midnatsbørn, som begge lader forrykkelsen af forholdet mellem det offentlige og det private manifestere sig i de mest forrykte grotesker.

Hovedpersonen i Bliktrommen er Oskar, den evigt treårige dværg, som fra romanens første sætning er placeret uden for det sociale fællesskab og den kollektive orden. Men Oskars »bekendelse« fører i romanens løb til en »erkendelse« hos læseren, der må sande, at den personlige misdannelse både er en refleks af og en reaktion på den politiske misdannelse i nazismens Tyskland og Polen.

Hovedpersonen i Midnatsbørn, Saleem Sinai, er med sin enorme næse og sin revnende krop et endnu mere grelt eksempel på kortslutningen mellem personlig og politisk udvikling, og selvom han står i telepatisk radiokontakt med de 1000 andre magiske midnatsbørn, der ligesom han

34. Marcel Beyer: Flyvende hunde, Kbh. 1997, p. 112.

35. David Daiches: The Novel and the Modern Worl, Chicago and London 1965, p.26 f. 
fødes i det øjeblik, den 15. august 1947, hvor Indien opnår uafhængighed, er denne »All-India-Radio« ikke i stand til at mediere mellem de mangfoldige stemmer, der hermed frigøres:

»De indre monologer hos alle de såkaldte myldrende millioner, af masser og klasser i lige grad, trængtes for at få plads inde i mit hoved. (...) Stemmerne plaprede i alt fra Malayalam til Naga-dialekter, fra Lucknow-urdus renhed til det slørede sydlige Tamil. $\aleph^{36}$

Massemedier som film og radio løser ikke Saleems problem med at finde en form eller i hvert fald en formel, der kan formidle mellem det offentlige og det private, det politiske og det personlige. Selv forklarer han grotesken som en art løsning på modsætningsforholdet mellem individ og masse: »...måske er det sådan, at vil man forblive et individ midt i de myldrende masser, må man gøre sig grotesk «. ${ }^{37}$ Men han kan ikke udforme den private sfære som en art mentalt beskyttelsesum, men er tværtimod pivåben for ydre påvirkninger og vel at mærke påvirkninger, som hele tiden skubber ham ud af kurs - og durk ind i historien:»...livet er blevet forvandlet til en groteske ved, at Historien brutalt er brudt ind i det ... $\aleph^{38}$

\section{Slutning}

I Den franske løjtnants kvinde overvejer den selvbevidste fortæller et sted, om han i stedet for fiktion har prøvet at pådutte læseren en fordækt essaysamling, og han nævner blandt de mulige essays ét om »Romanformens historie«. Vel, i enhver roman krydser mangfoldige historier romanens historie, i romangenren brydes genrens historie med andre institutioners historie, og i det hele taget kan man "historie for historie« trække meningsfulde linjer gennem romanens historie. I det 20 århundredes romanlitteratur ville en mediehistorisk linje først slå ned på udvekslingen mellem roman og film. Alan Spiegel beskriver samspillet i Fiction and the Camera Eye - og Nathalie Sarraute skitserer i L'ère du soupçon, ${ }^{39}$ hvordan filmens fremstilling af "runde« og levende karakterer sætter romanforfatteren fri i sin udforskning af det moderne menneske "uden egenskaber». Butors "stereofoniske prosa» viser, at også radiomediet har haft indflydelse, ligesom man kunne nævne, at

36. Salman Rushdie,: Midnatsbørn, Kbh. 1996, p. $187 \mathrm{f}$.

37. Op.cit., p. 120.

38. Op.cit., p. 62.

39. Nathalie Sarraute: L'ère du soupçon. Essais sur le roman, Paris 1956. 
William Gibson's Neuromancer med sit begreb om cyberspace har demonstreret, hvordan romanen befinder sig i fortsat udveksling med medieudviklingen. En kulturhistorisk linje ville i forlængelse heraf kunne vise, hvordan der fra 1960erne sker en påfaldende nedbrydning af skellet mellem kultur og massekultur - som når Rushdie i sin eksperimenterende underholdningsroman Midnatsbørn på én gang dekreterer og demonstrerer, at »ingen fra Bombay bør være foruden et elementært film-gloseforråd. $\star^{40}$ Socialhistorisk ophører borgerskabet med at være romanens omdrejningspunkt - forfatteren kan, som Robbe-Grillet formulerer det, ikke tage privatejendommen som det selvfølgelige perspektiv. En kønshistorisk linje ville kunne pege på en stærk forskydning mod romaner skrevet af kvinder, om kvinder og for kvinder - efter 1945 startende med Simone de Beauvoir og fulgt op af forfattere som Nathalie Sarraute, Marguerite Duras, Fay Weldon, A.S. Byatt, Toni Morrison og bestsellerlisternes legioner af kvindelige forfattere. En genrehistorisk linje ville kunne skitsere forandringer inden for romangenrer som f.eks. krimien og forandringer i forholdet mellem romangenrer som f.eks. essayromanens fremmarch og rejseromanens tilbagetog. Og dertil kunne der argumenteres for en række andre perspektiver, som hver især ville kunne identificere signifikante mønstre i romanens udvikling, i nærværende tilfælde forholdet mellem form og stof.

Doris Lessing skriver med indledningen til The Golden Notebook (1962) at hovedpersonen Anna Wulf fører ikke én, men fire af disse notesbøger, "fordi hun erkender, at hun må skille tingene ad, fordi hun frygter kaos, formløshed - sammenbrud «. ${ }^{41}$ Man kunne måske tilføje, at det overhovedet er gennem romanen, at historien lader sig erkende som andet end kaos.

40. Salman Rushdie: Midnatsbørn, Kbh. 1996, p. 35.

41. Doris Lessing: The Golden Notebook, London 1974, p. vii. 